\title{
Pola Komunikasi Organisasi Dalam Pengembangan Program Studi Filsafat Hindu STAH Negeri Mpu Kuturan Singaraja
}

\author{
I Putu Ariyasa Darmawan, I Made Gami Sandi Untara, Ni Wayan Juli Artiningsih \\ STAH Negeri Mpu Kuturan Singaraja \\ ariyasabent23@gmail.com, gamisandi@gmail.com, wayanjuliartiningsih23@gmail.com
}

\begin{tabular}{l}
\hline Keywords: \\
\hline Pattern, \\
Organizational \\
Communication, \\
Hindu \\
Philosophy Study \\
Program \\
\hline
\end{tabular}

Abstract
The STAH Negeri Mpu Kuturan Singaraja Hindu Philosophy
Study Program is a new study program with minimal interest in
prospective new students. Minimal in quantity, but the
organization in the study program is currently complete, both
lecturers, employees, and students. The minimum number of
lecturers and students requires a form of communication that
functions to unite study programs and minimize
misunderstandings in interpreting orders or information. The
purpose of this research is to be able to build a new concept of
communication in organizational culture within the Brahma
Widya Department which can later be applied for further
organizational progress. This research is a qualitative research
with a phenomenological approach. Sources of data in this study
were obtained by direct interviews and using several data
sources that are helpful in analyzing such as books on
communication. Data collection was carried out by observation,
interviews with purposive sampling method, literature study, and
documentation.
he forms of organizational communication in the Brahma Widya
Department in the development of the Hindu Philosophy Study
Program STAH Negeri Mpu Kuturan Singaraja are; 1) Message
delivery in organizational communication is what the leader
conveys to his subordinates, 2) Organizational Communication
Media, namely a) Interpersonal Media b) Group Media. 3)
Systems and Leadership in Organizations and Communication
Patterns in Hindu Philosophy Study Programs are carried out
officially and unofficially. It is officially carried out through
meetings, either in person or online, by letter or by an official
announcement. Informally carried out through simple
discussions or during lunch breaks or private approaches to the
other party. Each pattern certainly has its own advantages in the
success of a communication, so collaboration between official
and unofficial is carried out for the success of activities in the
Hindu Philosophy Study Program


Kata Kunci:

Pola, Komunikasi

Organisasi,

Program Studi

Filsafat Hindu

\begin{abstract}
Abstrak
Program Studi Filsafat Hindu STAH Negeri Mpu Kuturan Singaraja adalah prodi baru dengan minim minat calon mahasiswa baru. Minim secara kuantitas, namun organisasi di prodi saat ini lengkap, baik dosen, pegawai, dan mahasiswa. Minimnya jumlah dosen dan mahasiswa memerlukan bentuk komunikasi yang berfungsi menyatukan prodi dan meminimalisir kesalahpahaman dalam menafsirkan perintah atau informasi. Tujuan dari penelitian ini adalah dapat membangun suatu konsep baru tentang komunikasi dalam budaya organisasi di lingkungan Jurusan Brahma Widya yang nantinya dapat diterapkan untuk kemajuan organisasi selanjutnya. Penelitian ini merupakan penelitian kualitatif dengan pendekatan fenomenologi. Sumber data dalam penelitian ini yakni diperoleh dengan wawancara langsung dan menggunakan beberapa sumber data yang sifatnya membantu dalam menganasis seperti buku-buku tentang komunikasi. Pengumpulan data dilaksanakan dengan observasi, wawancara dengan metode purposive sampling, studi kepustakaan, dan dokumentasi.

Bentuk komunikasi organisasi di Jurusan Brahma Widya dalam pengembangan Prodi Filsafat Hindu STAH Negeri Mpu Kuturan Singaraja yaitu; 1) Penyampaian Pesan dalam komunikasi organisasi ini adalah apa yang disampikan oleh pimpinan kepada bawahannya, 2) Media Komunikasi Organisasi yaitu a) Media Antar Pribadi b) Media Kelompok. 3) Sistem dan Kepemimpinan Dalam Organisasi dan Pola Komunikasi di Program Studi Filsafat Hindu dilaksanakan secara resmi dan tidak resmi. Secara resmi dilaksanakan melalui rapat baik rapat langsung ataupun secara online, dengan surat ataupun sebuah pengumuman resmi. Secara tidak resmi dilakukan melalui diskusi sederhana atau saat istirahat siang atau pendekatan secara pribadi terhadap pihak lain. Setiap pola tentu memiliki kelebihan masing-masing dalam kesuksesan dari sebuah komunikasi, maka kolaborasi antara resmi dan tidak resmi dilaksanakan untuk kesuksesan kegiatan di Prodi Filsafat Hindu
\end{abstract}

\section{Pendahuluan}

Prodi Filsafat Hindu Jurusan Brahma Widya STAHN Mpu Kuturan Singaraja merupakan salah satu Prodi baru dan baru beroperasi pada tahun 2016. Pada saat itu sumber daya pengajar masih terbatas, ruang perkuliahan beerpindah-pindah, belum lengkapnya struktur pengelola prodi dan lain sebagainya. Akan tetapi hal ini tidak menjadi kendala untuk menjadi yang terbaik. Proses layanan akademik, kemahasiswaan, dan lainnya terus dilakukan dengan maksimal. Filsafat Hindu ini tergabung dalam Jurusan Brahma Widya STAHN Mpu Kuturan Singaraja. Jurusan ini didirikan karena 
kebutuhan masyarakat yang mendambakan generasi-generasi masa depan yang memiliki karakter tri kaya parisudha dan memiliki etika religius dalam beraktifitas sosial, selain itu juga jurusan ini didirikan karena memiliki tanggung jawab menghasilkan lulusan yang siap menjadi Konsultan Agama yang mampu menjelaskan keberagaman serta kontributif bagi pemberdayaan masyarakat dalam beragama, berbangsa dan bernegara Lulusan Prodi Filsafat Hindu masih diperlukan karena pengetahuannya dapat diterapkan langsung di masyarakat. Sehingga masyarakat dapat menerima secara langsung hasil dari penerapan ilmunya.

Prodi Filsafat Hindu merupakan Prodi yang langka dan sepi peminat dalam menarik minat siswa yang mau masuk ke Jurusan Brahma Widya STAHN Mpu Kuturan Singaraja, dibuktikan dengan beberapa catatan penting. Tahun 2016, pada penerimaan perdana Prodi Filsafat hanya dapat menerima mahasiswa baru sebanyak 2 orang, tahun 2017 sebanyak 5 orang, tahun 2018 sebanyak 12, di tahun 2019 hanya menerima mahasiswa 13 orang saja dan tahun 2020 sebanyak 20 mahasiswa, total mahasiswa di Prodi Filsafat hingga saat ini sebanyak 52 Orang. Sebagai Prodi baru untuk harus tetap eksis mempertahankannya didalam menghadapi persaingan antar-perguruan tinggi yang semakin ketat, keadaan itu merupakan masalah bagi lembaga sebagai lembaga pendidikan dan masyarakat sebagai pengguna jasa pendidikan.

Adanya 11 Prodi di STAHN Mpu Kuturan Singaraja, membuat Prodi Ilmu Filsafat harus mampu mengelola organisasinya dengan baik, dan sumber daya yang ada di dalamnya juga harus berfungsi dengan baik, supaya mampu bersaing dengan prodiprodi lain yang ada di dalam STAHN Mpu Kuturan Singaraja maupun UniversitasUniversitas lainnya. Oleh karena itu komunikasi organisasi sangat penting, seperti pendapat Zelko dan Dance yang berpendapat bahwa komunikasi organisasi itu berpaku pada sistem yang saling melengkapi satu sama lain baik di dalam internal organisasi maupun di luar organisasi itu sendiri (Ardial, 2018). Jadi, komunikasi organisasi yaitu proses mengolah sistem ke dalam bentuk pesan yang sudah Proses tersebut bisa terlaksana jika budaya organisasi dibentuk dan dipraktekkan dengan baik dilingkungan organisasi. Menurut Robbin, budaya organisasi adalah sebagai pola yang terdiri atas kepercayaan dan nilai-nilai yang memberi arti bagi anggota untuk berperilaku di organisasinya (Moeljono, 2006, 13).

Budaya organisasi dapat terlealisasi jika tujuan organisasi dibentuk dengan baik dan sudah direncanakan sebelumnya, supaya organisasi dapat berkembang seperti tujuan 
yang sudah diharkan. Sesuai dengan Peraturan Menteri Riset, Teknologi, Dan Pendidikan Tinggi Republik Indonesia Nomor 15 Tahun 2018 tentang Organisasi dan Tata Kerja Lembaga Layanan Pendidikan Tinggi, Pasal 23 bagian Sumber Daya Perguruan Tinggi sebagaimana dimaksud dalam Pasal 10 ayat (1) huruf d mempunyai tugas melaksanakan penyusunan bahan fasilitasi dan pemberian layanan di bidang sumber daya perguruan tinggi.

Robbins menjelaskan bahwa budaya organisasi menyangkut bagaimana para anggota melihat organisasi tersebut, bukan menyangkut apakah para anggota organisasi menyukainya atau tidak, karena para anggota menyerap budaya organisasi berdasarkan dari apa yang mereka lihat atau dengar di dalam organisasi. Anggota organisasi cenderung merepresentasikan sama tentang budaya dalam organisasi tersebut, meskipun mereka berasal dari latar belakang yang berbeda ataupun bekerja pada tingkat-tingkat keahlian yang berlainan dalam organisasi tersebut. Sehingga budaya organisasi dapat disimpulkan sebagai nilai-nilai yang menjadi pegangan sumber daya manusia dalam menjalankan kewajibannya dan juga perilakunya di dalam suatu organisasi.

Komunikasi yang efektif terjadi apabila individu mencapai pemahaman bersama, merangsang pihak lain melakukan tindakan, dan mendorong orang untuk berpikir dengan cara baru. Kemampuan untuk berkomunikasi secara efektif akan menambah produktifitas, baik individu yang bersangkutan maupun organisasinya, sehingga dapat mengantisipasi masalah, membuat keputusan secara efektif dan mengkoordinasikan arus kerja serta mengembangkan hubungan. Dalam organisasi khususnya di perguruan tinggi informasi yang disampaikan dari pimpinan kepada bawahan seringkali terlambat, diberlakukan adanya beban kerja dosen (BKD) yang diserahkan kepada pimpinan sebagai syarat untuk pencairan dana sertifikasi dosen, pada saat itu informasi yang diterima dosen sudah terlambat. Masalah lain yang muncul di adalah masalah daftar kehadiran dosen, dimana dosen dan karyawan mempunyai jam absen yang sama, sedangkan dosen mempunyai tugas yang berbeda yaitu melaksanakan tri dharma perguruan tinggi. Kemudian kurangnya apresiasi dan motivasi terhadap dosen- dosen atau karyawan yang ada di lingkungan kampus.

Optimalisasi organisasi yang ada di Jurusan Brahma Widya sangat penting bagi pengembangan Prodi Filsafat Agama Hindu, hal ini dikarenakan isu ini akan berdampak besar bagi calon mahasiswa baru, kompetensi lulusan Prodi Filsafat Agama Hindu, dan 
bagi kredibelitas STAHN Mpu Kuturan sebagai penyelenggara pendidikan, hal tersebut dilihat dari beberapa permasalahan sebagai berikut :

1. Prodi Filsafat Agama Hindu merupakan Prodi yang langka dan sepi peminat, sehingga tiap tahun sangat sulit dalam mencari mahasiswa.

2. Prodi Filsafat Agama Hindu kurang dikenal secara luas oleh masyarakat sehingga berpengaruh terhadap citra dan kredibelitas lembaga kedepannya.

3. Sebagai Prodi baru untuk harus tetap eksis mempertahankannya didalam menghadapi persaingan antar-perguruan tinggi yang semakin ketat, keadaan itu merupakan masalah bagi lembaga sebagai lembaga pendidikan dan masyarakat sebagai pengguna jasa pendidikan.

4. Sebagai kampus berbasic Agama Hindu tentu citra negatif terhadap lulusan, citra negatif terhadap kredibelitas institusi, dan juga akan mempengaruhi nilai kompetensi lulusan atau output institusi.

Prodi Filsafat Hindu masih diperlukan karena pengetahuannya dapat diterapkan langsung di masyarakat. Sehingga masyarakat dapat menerima secara langsung hasil dari penerapan ilmunya. Dunia nasional juga membutuhkan hasil dari pengembangan ilmu pengetahuan religius yang dapat dituangkan dari karya tulis yang dapat diakses di dunia digital. Sistem yang tidak hanya dibuat secara konvensional, namun sudah berbasis teknologi digital juga memberikan dampak yang positif bagi perkembangan ilmu pengetahuan dan teknologi yang berguna bagi masyarakat.

\section{Metode}

Penelitian ini merupakan penelitian lapangan, yaitu jenis penelitian kualitatif, dengan pendekatan fenomenologi yang berakar pada latar alamiah sebagai keutuhan. Lokasi penelitian adalah di Prodi Filsafat Hindu STAH Negeri Mpu Kuturan Singaraja. Penelitian ini menggunakan data kualitatif, diungkapkan dalan bentuk kalimat serta uraian-uraian bahkan dapat berupa cerita pendek pada beberapa data tertentu, dapat menunjukkan perbedaan dalam bentuk jenjang atau tingkatan, walaupun tidak jelas batasbatasnya. Ada dua sumber data dalam penelitian ini yakni data primer, diperoleh langsung dengan wawancara langsung terhadap ketua-ketua organisasi di lingkungan Jurusan Brahma Widya, seperti Ketua Jurusan, Kaprodi, Ketua HMJ, dan ketua HMPS. Sedangkan data sekunder, menggunakan beberapa sumber data yang sifatnya membantu dalam menganasis seperti buku-buku tentang komunikasi. 
Dalam penelitian ini digunakan beberapa teknik pengumpulan data yaitu observasi, wawancara dengan metode purposive sampling, studi kepustakaan, dan dokumentasi. Adapun instrumen yang diperlukan dalam pengumpulan data untuk penelitian ini yaitu panduan wawancara, kamera foto digital, alat tulis, kertas, perekam suara, dan telepon genggam. Selanjutnya, dalam menyusun rancangan studi, draf hasil penelitian, dan laporan penelitian dibutuhkan seperangkat komputer atau laptop. Analisis data dalam penelitian ini menggunakan deskriftif kualitatif dengan pendekatan fenomenologi, sehingga data dikumpulkan dari berbagai sumber baik primer dan sekunder dan diproses atau di analisis dengan mengunakan pendekatan logika induktif.

\section{Hasil dan Pembahasan}

\section{Bentuk komunikasi organisasi di Jurusan Brahma Widya dalam pengembangan Prodi Filsafat Hindu STAH Negeri Mpu Kuturan Singaraja}

Hasil penelitian dengan metode wawancara dan observasi dengan beberapa pihak yang berkenaan langsung dengan penelitian serta data tambahan berupa dokumen Jurusan Brahma Widya dan Prodi Filsafat Hindu yang dapat menbantu penulis dalam meneliti. Data tambahan yang dimaksud dalam penelitian ini adalah dokumen tentang profil struktur organisasi dan beberapa data lainnya. Organisasi yang ada di Jurusan Brahma Widya yang bertujuan untuk pengembangan Program Studi Filsafat Hindu yang terjadi di dalam organisasi tersebut.

Maka dari itu perlu mengetahui dan memahami bentuk komunikasi organisasi dalam mengembangkan Prodi Filsafat Hindu STAHN Mpu Kuturan Singaraja memang penting di lakukan untuk mencapai tujuan dan keberlangsungan organisasi. Jika di dalam sebuah organisasi tidak mengetahui dan memahami bentuk komunikasi maka tujuan organisasi itu tidak akan berjalan dengan apa yang di inginkan. Untuk itu dalam suatu organisasi dibutuhkan pemahaman mengenai bentuk komunikasi yang di lakukan untuk mencapai tujuan Bersama.

\section{a. Komunikasi Organisasi}

Komunikasi Organisasi adalah pengiriman dan penerimaan organisasi dalam komunikasi yang kompleks. Yang termasuk dengan bidang ini adalah komunikasi internal, hubungan manusia, hubungan persatuan pengelola, komunikasi downward, komunikasi upward, dan lain-lain (Muhammad, 2007: 67). Komunikasi organisasi yang terjadi dalam suatu sistem terbuka yang kompleks yang dipengaruhi oleh lingkungannnya 
sendiri baik internal maupun eksternal. Selain itu Komunikasi Organisasi lengkap adalah pengiriman dan penerimaan berbagai pesan organisasi di dalam kelompok formal maupun informal dari suatu organisasi. Komunikasi formal adalah komunikasi yang disetujui organisasi itu sendiri dan sifatnya berorientasi kepentingan organisasi. Isinya berupa cara kerja dalam organisasi, prodiktivitas, dan berbagai pekerjaan yang harus dilakukan dakam organisasi. Misalnya: memo, kebijakan, pertanyaan, jumpa pers, dan surat-suratresmi. Adapun komunikasi informal adalah komunikasi yang disetujui secara sosial (Romli, $2014: 2)$.

Komunikasi organisasi yang terjadi adalah menyajikan suatu konsepsi komunikasi bagi suatu organisasi tertentu berdasarkan jenis organisasi, sifat organisasi, dan lingkup organisasi dengan memperhitungkan situasi tertentu pada saat komunkasi di lakukan. Proses dalam suatu organisasi adalah suatu sistem terbuka yang dinamis yang menciptakan dan saling menukar pesan diantara anggotanya. Karena gejala menciptakan dan menukar informasi ini berjalan terus menerus dan tidak ada henti-hentinya maka dikatakan sebagai suatu proses. Pesan dalam komunikasi organisasi ini adalah apa yang disampikan oleh pimpinan kepada bawahannya.

Pesan ini bisa berisi tentang tugas-tugas dalam organisasi, pemeliharaan organisasi dan kemanusiaan. Pesan yang berkenaan dengan tugas-tugas yaitu yang berhubungan dengan produksi organisasi, pelayanan dan kegiatan khusus yang berkenaan dengan organisasi. Pesan yang berkenaan dengan pemeliharaan organisasi seperti kebijaksanaan, aturan-aturan yang membantu organisasi tetap hidup. Sedangkan pesan yang berkenaan dengan kemanusiaan adalah mengenai sikap karyawan, moral, rasa kepuasan, dan pemenuhan kebutuhan anggota organisasi. Jaringan dalam organisasi ini adalah hakikat dan luas jaringan komunikasi yang dipengaruhi oleh banyak faktor, antara lain hubungan peranan, arah dan arus pesan. Seperti yang diungkapkan oleh I Wayan Gata selaku Ketua Jurusan Brahma Widya sebagai berikut ini.

"dalam mencapai tujuan organisasi maka yang diperlukan adalah strategi komunikasi merupakan paduan dari perencanaan koumunikasi (communication planning) dan manajemen (management communications) untuk mencapai suatu tujuan. Untuk mencapai suatu tujuan dalam organisasi tidak terlepas dari strategi komunikasi yang dilakukan. Strategi komunikasi tersebut harus menunjukkan bagaimana operasionalnya secara taktis harus dilakukan, dalam arti kata bahwa pendekatan bisa berbeda sewaktu- 
waktu, bergantung kepada situasi dan kondisi misalnya gaya berkomunikasi dengan pimpinan, dosen, pegawai dan mahasiswa di kampus ini” (wawancara, 18 juni 2021).

Berdasarkan penyampaian dari Ketua Jurusan Brahma Widya maka peranan tingkah laku dalam suatu organisasi menentukan siapa yang menduduki posisi atau pekerjaan tertentu baik dinyatakan secara formal maupun non formal. Arah jaringan komunikasi ada yang disebut jaringan komunikasi kepada bawahan, komunikasi kepada atasan dan komunikasi horisontal. Arus pesan ini adalah aliran pesan yang disampaikan oleh pimpinan yang terkadang disampaikan secara lisan, dan karena disampaikan secara berantai terkadang pesan ini sudah tidak lengkap lagi. Saling tergantung Konsep kunci komunikasi yang lainnya yaitu keadaan yang saling bergantung satu bagian dengan bagian lainnya. Hal ini telah menjadi sifat dari suatu organisasi yang merupakan suatu sistem terbuka.

Bila suatu bagian dari organisasi mengalami gangguan maka akan berpengaruh kepada bagian lainnya. Hubungan manusia dalam organisasi yang memfokuskan kepada tingkah laku komunikasi dari orang yang terlibat dalam suatu hubungan. Hubungan manusia dalam organisasi berkisar dari yang sederhana yaitu hubungan antara dua orang sampai kepada hubungan yang kompleks.

\section{b. Media Komunikasi Organisasi}

Terdapat beberapa macam media komunikasi dalam organisasi. Media adalah alat atau sarana yang di gunakan untuk menyampaikan pesan dari komunikator kepada komunikan (khalayak). Media komunikasi yang digunakan dalam organisasi antara lain adalah :

1) Media Antar Pribadi (Interpersonal Comunication)

Media komunikasi antar pribadi salah satunya adalah telepon. Sejak di temukannyna teknologi selular, penggunaan telepon genggam (handphone) semakin marak di kalangan anggota masyarakat. Ini pertanda bahwa telepon selular tidak lagi di maksudkan sebagai simbol prestise, melainkan lebih banyak di gunakan untuk kepentingan bisnis, kantor, organisasi dan urusan keluarga. Komunikasi di atas menjelaskan bahwa dengan adanya komunikasi antar pribadi akan lebih mudah memberikan informasi dalam kepentingan pribadi atau kepentingan bisnis dan juga organisasi.

Dalam Jurusan Brahma Widya Prodi Filsafat Hindu Komunikasi antar pribadi (interpersonal communication) digunakan sebagai alat komunikasi antar ketua Jurusan, 
Ketua Prodi, Dosen, dan Pegawai sebagai suatu hal yang sangat penting, dimana komunikasi sebagai alat atau sebagai media yang menjembati dalam hubungan antar sesama anggota. Di era milenial seperti ini juga diterapkan melalui media handphone ketika melakukan komunikasi jarak jauh yaitu ketika ada anggota dosen yang tidak bisa menghadiri agenda yang dijalankan maka langsung bisa memantau hasil yang di publikasikan lewat grup social media. Selain itu juga dengan komunikasi secara personal dengan media handphone merupakan salah satu strategi yang digunakan. Seperti yang diungkapkan oleh Krisna Sukma Yogiswari selaku Kaprodi Filsafat Hindu sebagai berikut ini.

Prodi Filsafat Hindu mempunyai group chating di social media bisa dijadikan salah satu strategi komunikasi, jadi misalkan ada salah satu dari anggota dosen tidak bisa mengikuti rapat atau menghadiri acara pada hari yang ditentukan, maka sekprodi bisa share hasil rapat di group. Jadi seluruh dosen yang pada saat itu tidak hadir masih bisa mengikuti perkembangannya. Selain itu juga apabila ada yang berhalangan hadir pada kegiatan tersebut, agar tidak terjadi perpecahan di prodi tersebut selalu dipantau, terkait orang tersebut. Jadi didalam suatu organisasi mereka tidak berjalan sendiri, maksudnya agar ada sebab dan akibat, serta alasannya (wawancara, 27 Juni 2021)

Berdasarkan wawancara tersebut penggunaan group online untuk rapat internal Prodi Filsafat sangat efisien dan efektif dalam menyampaikan suatu informasi apapun yang terkait dengan organisasi. Namun dalam setiap penyampaian segala bentuk informasi di group online tidak semuanya para anggota dapat dengan cepat meresponnya. Hal ini disebabkan karena semua anggota memiliki kesibukannya tersendiri dan juga banyaknya group online yang diikuti dalam aplikasi androitnya. Seperti yang diungkapkan oleh anggota sekretaris Prodi Filsafat Hindu berikut ini.

...untuk meningkatkan dan menjaga hubungan baik antar sesama anggota Prodi Filsafat Hindu, dan juga menjaga komunikasi yang baik melalui media sosial group online ini sangat bagus dan saya sangat setuju akan hal ini. Namun, dalam kesehariannya menurut saya pribadi, tidak semua anggota sempat membuka group online-nya setiap saat karena berbagai kesibukan. Maka dari itu, dirasa sangat perlu pimpinan secara langsung untuk chat personal kepada para anggotanya. Hal ini bertujuan untuk lebih mempercepat respon komunikasi yang didapat dari para Dosen Prodi Filsafat Hindu (wawancara, 18 Juli 2021).

Berdasarkan kutipan wawancara tersebut menjelaskan bahwa, tidak cukup hanya pada rapat group online namun, untuk lebih mempercepat mendapat jawaban dari para anggota Prodi Filsafat Hindu maka diperlukan juga komunikasi antar pribadi atau chat personal atasan langsung ke para anggota. Cara ini merupakan salah satu strategi yang dapat digunakan untuk lebih meningkatkan komunikasi dalam organisasi ini. 
Tidak jarang antara pesan yang disampaikan oleh pengirim pesan kepada penerima pesan mengalami distorsi. Penyebabnya antara lain karena interaksi yang terganggu oleh adanya kekurangpahaman penerima pesan, miss komunikasi, dan media yang buruk. Bias muncul karena komunikasi yang terjadi hanyalah bersifat searah. Maka dari itu, komunikasi di dalam suatu organisasi Prodi Filsafat Hindu harus dua arah yakni terdiri dari komunikasi ke atas dan komunikasi ke bawah. Dua arah komunikasi atas bawah dan bawah atas sangat penting untuk mencapai keberhasilan tujuan bersama dalam organisasi Prodi Filsafat Hindu.

2) Media Kelompok

Aktivitas komunikasi yang melibatkan khalayak lebih dari 15 orang, maka media komunikasi yang lebih banyak di gunakan media kelompok. Dalam Jurusan Brahma Widya Prodi Filsafat Hindu media kelompok ini digunakan jika pertemuan melibatkan banyak orang Misalnya rapat, seminar dan konferensi. Rapat biasanya di gunakan untuk membicarakan hal-hal penting yang di hadapi oleh suatu organisasi di Jurusan Brahma Widya maupun Prodi Filsafat Hindu. Media kelompok yang dimiliki oleh Jurusan Brahma Widya atau organisasi lainnya. Media kelompok memudahkan banyak khalayak untuk menjalankan komunikasi dan bertukar informasi dengan cepat dan lebih mudah untuk dibicarakan secara langsung agar tidak terjadi kesalahpahaman antara satu dengan yang lainnya. Hal serupa juga di ungkapkan oleh I Made Hartaka selaku Sekretaris Jurusan Brahma Widya sebagai berikut:

Banyak strategi komunikasi yang dapat kita terapkan dalam komunitas / organisasi.. seperti communication technology (bisa melalui mobile phone, pc, dan teknologi komunikasi modern lainya). Ini hanya sebagian kecil dari communication technology. Yang bisa sangat membantu dalam memanage sebuah komunitas atau organisasi. Inilah bentuk komunikasi modern yang mempermudah kita. Tapi kelemahan nya adalah kurang nya kedekatan secara batin, karena semua sebatas dan terbatas technology. Kita ingin meningkatkan solidaritas dengan sesama manusia dengan technology dan manfaatkan technology sebagai media untuk kita semakin solid. Jadikan technology media product human relations, jaman semakin maju. Metode / strategy untuk pengembangan dan peningkatan komunikasi dalam sebuah komunitas dan organisasi Akan semakin banyak dan variatif. kita sebagai Manusia organisasi dituntut untuk creative Dan inovatif. (wawancara dengan 29 Juni 2021 Pukul 10.00 Wita).

Berdasarkan hal tersebut Keberhasilan komunikasi dua arah di dalam suatu organisasi akan ditentukan oleh kesamaan pemahaman antara civitas Jurusan Brahma Widya terutama di Prodi Filsafat Hindu yang terlibat dalam kegiatan komunikasi. 
Kesamaan pemahaman ini dipengaruhi oleh kejelasan pesan, cara penyampaian pesan, perilaku komunikasi, dan situasi (tempat dan waktu) komunikasi. Komunikasi organisasi biasanya menggunakan kombinasi cara berkomunikasi (lisan, tertulis dan tayangan) serta didukung oleh kecanggihan teknologi yang tersedia saat ini. Hal tersebut yang memungkinkan terjadinya penyerapan informasi dengan lebih mudah dan jelas. Secara empiris, pemahaman para anggota Prodi Filsafat Hindu perihal sesuatu hal akan lebih mudah diserap dan dipahami jika sesuatu tersebut diperlihatkan dibanding hanya diperdengarkan atau dibacakan.

\section{c. Sistem dan Kepemimpinan Dalam Organisasi}

Organisasi memiliki berbagai tipe gaya manajemen, Likert menyatakan adanya empat sistem manajemen yang utama, yaitu eksploitatif-otoritatif, benevolen-otoritatif, konsultatif, dan kelompok partisipatif (Morisson, 2009:71). Manajemen eksploitatif tidak terlalu memikirkan komunikasi, kecuali untuk menyatakan keinginan secara jelas dan memaksa kepada bawahan. Dalam hal ini terdapat sedikit komunikasi dari bawah ke atas dan kalaupun ada, cenderung untuk mengalami distorsi. Para manajer dan bawahannya tidak memiliki hubungan dekat dan tidak terdapat banyak saling pengertian di antara mereka. Jika manajemen otoritatif, maka sulit bagi karyawan untuk memiliki loyalitas kepada organisasi, lebih banyak konflik yang muncul, kurang adanya dukungan dari bawah dan tidak banyak menghasilkan motivasi bagi karyawan. Hal ini akan memberi hasil negatif pada organisasi. Hal serupa juga di ungkapkan oleh I Made Hartaka selaku Sekretaris Jurusan Brahma Widya sebagai berikut:

Pada Jurusan Brahma Widya Prodi Filsafat Hindu memiliki manajemen konsultatif dan kelompok partisipatif akan menghasilkan loyalitas dan kinerja untuk mencapai target yang lebih tinggi, adanya dukungan dari bawah, serta munculnya sikap bawahan yang lebih positif. Selain itu, para dosen memiliki motivasi lebih tinggi yang akan menghasilkan loyalitas yang besar. Manajemen partisipatif juga memiliki arus komunikasi dua arah, dari atas ke bawah dan dari bawah ke atas sehingga komunikasi cenderung memiliki hubungan yang dekat dan memiliki saling pengertian satu sama lainnya. Organisasi yang menggunakan sistem otoriter-eksploitatif memberikan hasil negatif buat organisasi, sedangkan sistem partisipatif memberikan hasil yang positif buat organisasi (wawancara dengan 29 Juni 2021 Pukul 10.00 Wita).

Berdasarkan wawancara tersebut bahwa efektivitas organisasi harus dapat menggambarkan seluruh siklus input proses dan output proses, dan juga harus menggambarkan hubungan timbal balik yang harmonis antara organisasi dengan lingkungan yang lebih luas. 


\section{Fungsi komunikasi organisasi di Jurusan Brahma Widya dalam pengembangan prodi Filsafat Hindu STAHN Mpu Kuturan Singaraja.}

Komunikasi saat ini sangat penting karena perkembangan teknologi komunikasi yang semakin inovatif. Selain itu, kemajuan teknologi komunikasi bisa mengaburkan batas-batas geografis atau wilayah. Kemunculan alat-alat elektronik dengan kecanggihannya menyebabkan teknologi komunikasi berkembang dengan pesat, contohnya adalah perkembangan smartphone dan teknologi internet yang memudahkan orang untuk melakukan komunikasi tanpa dibatasi jarak dan waktu. Perkembangan teknologi komunikasi juga diikuti oleh kehadiran berbagai platform media sosial yang banyak digunakan oleh individu, kelompok, maupun organisasi sebagai media komunikasi.

Komunikasi merupakan hal yang wajib dalam kehidupan manusia, sehingga perlu membangun komunikasi yang baik agar dapat tercipta hubungan yang harmonis dengan orang lain. Komunikasi menjadi kunci utama dalam proses pertukaran informasi antar bagian dalam suatu organisasi atau lembaga. Organisasi atau lembaga yang baik dapat terwujud apabila komponen-komponen didalamnya berfungsi secara maksimal. Suatu organisasi yang baik terdapat fungsi-fungsi material atau manajemen yaitu seperti: perencanaan (planning), pengorganisasian (organizing), perintah (commanding), koordinasi (coordinating), penilaian (evaluating), dan pengembangan (developing)

Komunikasi organisasi adalah pengiriman dan penerimaan informasi dalam organisasi yang kompleks, yang termasuk dengan bidang ini adalah komuikasi internal, hubungan manusia, hubungan persatuan pengelola, komunikasi dari bawahan kepada atasan, komunikasi horizontal atau komunikasi dari orang-orang yang sama level/tingkatnya dalam organisasi, keterampilan komunikasi dan berbicara, mendengarkan, menulis, dan komunikasi evaluasi program.

Devito (1997: 340) mendefinisikan komunikasi organisasi sebagai pengiriman dan penerimaan berbagai pesan dalam organisasi, baik dalam kelompok formal maupun kelompok informal organisasi. Wiryanto (2004:54), menyebutkan komunikasi organisasi adalah pengiriman dan penerimaan berbagai pesan organisasi di dalam kelompok formal maupun informal dari suatu organisasi. Seperti yang diungkapkan oleh Krisna Sukma Yogiswari selaku Kaprodi Filsafat Hindu sebagai berikut ini.

Komunikasi di Program Studi Filsafat Hindu, saat situasi pandemi seperti sekarang, segala bentuk komunikasi baik resmi maupun tidak resmi, dilakukan secara langsung dan online. Penentuan kebijakan atau keputusan di tingkat 
pimpinan Program Studi Filsafat Hindu dilakukan secara langsung karena pimpinan Prodi ada dalam sistem kerja WFH (Work From Home), sementara hasil keputusan yang akan disampaikan kepada seluruh dosen dan pegawai dilakukan secara online (Wawancara, 27 Juni 2021).

Berdasarkan hal tersebut Komunikasi dalam bentuk koordinasi, dilakukan secara online melalui aplikasi zoom yang membuat semua dosen dan pegawai mampu menyampaikan saran atau pendapatnya secara langsung, sedangkan edaran atau pengumuman disampaikan dalam group WhatsApp yang nantinya akan direspon oleh semua dosen dan pegawai. Salah satu media sosial yang saat ini sedang ramai digunakan untuk melakukan komunikasi dan interaksi oleh masyarakat, tidak terkecuali organisasi dan lembaga pemerintah, adalah WhatsApp atau Zoom. Munculnya sarana ini memudahkan manusia berkomunikasi dalam situasi pandemi yang mengharuskan manusia menjaga jarak dan menghindari kerumunan. Aplikasi WhatsApp dan Zoom digunakan di Program Studi Filsafat Hindu untuk melaksanakan rapat atau perkuliahan.

WhatsApp Messenger adalah aplikasi pesan untuk ponsel cerdas. WhatsApp Messenger merupakan aplikasi pesan lintas platform yang memungkinkan kita bertukar pesan tanpa pulsa, karena WhatsApp Messenger menggunakan paket data internet. Aplikasi WhatsApp Messenger menggunakan koneksi internet $\underline{3 \mathrm{G}}$, $\underline{4 \mathrm{G}}$ atau WiFi untuk komunikasi data. WhatsApp dapat melakukan obrolan daring, berbagi file, bertukar foto, dan lain-lain. WhatsApp tidak terbatas oleh kelas sosial ekonomi tertentu, melainkan digunakan oleh semua kelas, mulai ekonomi rendah, menengah, hingga ekonomi atas. Pada perkembangan selanjutnya, aplikasi WhatsApp ini tidak hanya dimanfaatkan untuk berkomunikasi dan bertukar pesan, akan tetapi saat ini WhatsApp juga dimanfaatkan untuk kepentingan pekerjaan, tidak jarang sebuah perusahaan atau instansi pemerintah menggunakan media ini untuk berkomunikasi dengan para staf/karyawan dan pegawai. Pimpinan perusahaan atau instansi biasanya memanfaatkan layanan group chat yang tersedia dengan tujuan agar informasi yang disampaikan menjadi lebih menyeluruh tanpa harus mengirim informasi satu per satu. Selain itu dengan adanya group chat tersebut komunikasi antar pegawai beserta pimpinan bisa lebih efektif.

Organisasi di Jurusan Brahma Widya STAHN Mpu Kuturan Singaraja tidak hanya terdiri dari struktur dosen dan pegawai, namun juga ada organisasi kemahasiswaan yang ada di bawah naungan Jurusan atau Program Studi Filsafat Hindu. Organisasi kemahasiswaan merupakan kelengkapan Jurusan atau Program Studi untuk mewujudkan 
visi misi dan juga sebagai bentuk kaderisasi mahasiswa untuk lebih memahami administrasi dan berorganisasi. Pola komunikasi di Jurusan Brahma Widya khususnya pada Prodi Filsafat Hindu tidak hanya terbatas pada pola komunikasi dari pimpinan saja, tetapi juga bagaimana bawahan ikut memberi sumbang saran kepada pimpinan untuk mencapai tujuan bersama. Seperti yang diungkapkan oleh Krisna Sukma Yogiswari selaku Kaprodi Filsafat Hindu sebagai berikut ini.

Dengan pola komunikasi yang baik akan dapat menciptakan iklim komunikasi yang baik juga. Pola komunikasi yang terlihat di lembaga ini adalah dengan menggunakan media tertulis contohnya dengan diterbitkannya Jurnal Prodi Filsafat Hindu yaitu Genta Hredaya, dan juga dengan diadakannya rapat-rapat yang bertujuan untuk membahas masalah yang ada. Pola komunikasi yang ada di Jurusan Brahma Widya pada Prodi Filsafat Hindu lebih banyak menggunakan pola komunikasi dari atasan ke bawahan, ini dapat terlihat dari adanya instruksi lisan atau tulisan, berupa surat undangan rapat, surat tugas dan rapat sebagai media komunikasi dalam organisasi menunjukkan bahwa komunikasi dari atasan lebih banyak dilakukan, sedangkan komunikasi dari bawahan yang lebih sedikit dipergunakan, ini terlihat dari rapat-rapat yang diadakan. Rapat hanya diadakan jika ada yang perlu dibicarakan atau ketika ada masalah yang memerlukan usulan dari bawahan (wawancara 27 juni 2021)

Berdasarkan hal tersebut dalam komunikasi organisasi Ketua Jurusan Brahma Widya dan Kaprodi Filsafat Hindu juga perlu mendengarkan atau mengetahui masukanmasukan atau saran-saran dari para dosen dan pegawai, karena itu komunikasi dari para dosen maupun pegawai dapat menunjukkan bahwa Ketua Jurusan menghargai bawahannya dan mendengarkan serta berinteraksi dengan bawahannya sehingga membentuk dasar bagi sebuah komunikasi yang efektif, dan salah satu bentuknya dengan meluangkan waktu untuk pertemuan tatap muka. Dengan adanya komunikasi dari bawahan kepada atasan dimana Ketua Jurusan dan Kaprodi dapat mengetahui pertama informasi tentang keberhasilan, kemajuan, dan rencana-rencana mendatang dari para bawahan. Kedua informasi tentang problem-problem pekerjaan yang memerlukan bantuan dari tingkatan lebih atas dalam organisasi. Ketiga Ide-ide untuk perbaikan dalam aktivitas dan fungsi yang berhubungan dengan pekerjaan. Keempat Informasi mengenai perasaan para bawahan tentang pekerjaan atau isu yang berhubungan dengan pekerjaan. Karena komunikasi dari bawahan kepada atasan mempunyai fungsi yang sangat penting dalam meningkatkan kinerja organisasi maka komunikasi dari bawahan kepada atasan ini perlu ditingkatkan agar anggota organisasi baik dosen ataupun pegawai adminstrasi merasa dihargai kehadirannya dan juga dapat diberikan solusi ketika mempunyai masalah, terutama masalah dalam menjalankan pekerjaannya 


\section{Kesimpulan}

Berdasarkan uraian tersebut, bentuk komunikasi organisasi di Jurusan Brahma Widya dalam pengembangan Prodi Filsafat Hindu STAH Negeri Mpu Kuturan Singaraja yaitu; 1) Penyampaian Pesan dalam komunikasi organisasi ini adalah apa yang disampikan oleh pimpinan kepada bawahannya, 2) Media Komunikasi Organisasi yaitu a) Media Antar Pribadi yaitu di Prodi Filsafat Hindu komunikasi antar pribadi digunakan sebagai alat komunikasi antar ketua Jurusan, Ketua Prodi, Dosen, dan Pegawai sebagai suatu hal yang sangat penting, dimana komunikasi sebagai alat atau sebagai media yang menjembati dalam hubungan antar sesama anggota. b) Media Kelompok dalam Jurusan Brahma Widya Prodi Filsafat Hindu media kelompok ini digunakan jika pertemuan melibatkan banyak orang. 3) Sistem dan Kepemimpinan dalam Organisasi yaitu pada Prodi Filsafat Hindu memiliki manajemen konsultatif dan kelompok partisipatif.

Fungsi komunikasi organisasi di Jurusan Brahma Widya dalam pengembangan prodi Filsafat Hindu STAHN Mpu Kuturan Singaraja yaitu Pola Komunikasi di Program Studi Filsafat Hindu dilaksanakan secara resmi dan tidak resmi. Secara resmi dilaksanakan melalui rapat baik rapat langsung ataupun secara online, dengan surat ataupun sebuah pengumuman resmi. Secara tidak resmi dilakukan melalui diskusi sederhana atau saat istirahat siang atau pendekatan secara pribadi terhadap pihak lain. Setiap pola tentu memiliki kelebihan masing-masing dalam kesuksesan dari sebuah komunikasi, maka kolaborasi antara resmi dan tidak resmi dilaksanakan untuk kesuksesan kegiatan di Prodi Filsafat Hindu

\section{Daftar Pustaka}

Ardial. (2018). Fungsi Komunikasi Organisasi Studi Kasus Tentang Fungsi Komunikasi Organisasi Terhadap Kinerja Pegawai, Medan: Lembaga Penelitian dan Penulisan Ilmiah Aqli.

Arni, M. (2005). Komunikasi Organisasi, Jakarta: PT. Bumi Aksara.

Cangara, H. (2007). Pengantar ilmu Komunikasi. Jakarta: Rajawali Pers.

Devito, J. A. (1997). Komunikasi Antar Manusia : Kuliah Dasar Edisi ke lima (Agus Maulana. Terjemahan). Jakarta : Professional Book

Muhammad, A.(1995). Komunikasi Organisasi, Jakarta: Bumi Aksara.

Moeljono, D. (2006). Budaya Organisasi Dalam Tantangan, Jakarta.: PT Alex Media Komputindo. 
Morissan. (2009). Teori Komunikasi Organisasi. Bogor: Ghalia Indonesia.

Purwanto,D. (2006). Komunikasi Bisnis, Edisi ketiga. Jakarta: Erlangga

Romli, K. (2014). Komunikasi Organisasi Lengkap. Jakarta: Grasindo.

Wiryanto.(2004). Pengantar Ilmu Komunikasi.Jakarta: PT. Grasindo.

Wijaya, I. S. (2013). Dinamika komunikasi organisasi di perguruan tinggi. Jurnal Dakwah Tabligh, 14(2), 203-215.

Wursanto, Ig. (2005). Dasar-Dasar Ilmu Organisasi. Yogyakarta: Andi. 